Article

\title{
The Effect of Phenazine-1-Carboxylic Acid on the Morphological, Physiological, and Molecular Characteristics of Phellinus noxius
}

\author{
Huazhi Huang ${ }^{1,2}$, Longhua Sun ${ }^{2}$, Keke Bi ${ }^{2}$, Guohua Zhong ${ }^{1}$ and Meiying $\mathrm{Hu}{ }^{1, *}$ \\ 1 Key Laboratory of Natural Pesticide and Chemical Biology, College of Agriculture, \\ South China Agricultural University, Guangzhou 510642, China; scauhhz@163.com (H.H.); \\ guohuazhong@scau.edu.cn (G.Z.) \\ 2 Guangzhou Insitute of Forestry and Landscape Architecture, Guangzhou 510405, China; \\ senlonghua@163.com (L.S.); gzbikeke@163.com (K.B.) \\ * Correspondence: humy@scau.edu.cn; Tel.: +86-20-8528-0064; Fax: +86-20-8528-0292 \\ Academic Editor: Derek J. McPhee \\ Received: 8 March 2016; Accepted: 5 May 2016; Published: 11 May 2016
}

\begin{abstract}
In this study, the effect of phenazine-1-carboxylic acid (PCA) on morphological, physiological, and molecular characteristics of Phellinus noxius has been investigated, and the potential antifungal mechanism of PCA against $P$. noxius was also explored. The results revealed that PCA showed in vitro antifungal potential against $P$. noxius and completely inhibited $P$. noxius hyphae at concentrations $>40 \mu \mathrm{g} / \mathrm{mL}$. PCA inhibited both mycelial growth and the loss of mycelial biomass in vitro in a dose-dependent manner. Morphological changes in PCA-treated P. noxius hyphae, such as irregularly swollen mycelia as well as short hyphae with increased septation and less branching, were observed by optical microscopy. The intracellular reactive oxygen species (ROS) levels were significantly increased in PCA-treated P. noxius cells as compared to control groups. Induced hyperpolarization of the mitochondrial membrane potential (MMP), repressed superoxide dismutase (SOD) activity and up-regulated gene expression of seven tested genes were also found in PCA-treated P. noxius groups. Thus, the present results suggested that the mechanism of action of PCA against $P$. noxius might be attributed to direct damage of mycelium and high intracellular ROS production, and indirect induction of genes involved in cell detoxification, oxidation-reduction process, and electron transport of the respiratory chain.
\end{abstract}

Keywords: antifungal activity; phenazine-1-carboxylic acid; Phellinus noxius; mycelia morphology; biological characterization; reactive oxygen species; gene expression

\section{Introduction}

Phellinus noxius is the casual agent of brown root rot disease, which can cause slow and reduced growth in trees, discoloration and wilting of leaves, defoliation, and dieback of branches and eventually lead to death [1,2]. The fungus was first reported in Singapore by Corner in 1932 as Fomes noxius and reclassified by Cunningham in 1965 as P. noxius [3]. It is widely distributed in tropical and sub-tropical regions of Southeast and East Asia, Oceania, Central America, Australia and Africa [2]. According to previous reports, the fungus has a very wide host range and shows little host specificity $[1,3,4]$. To date, more than 200 agricultural and forest plant species representing 59 families have been recorded as host plants, most of which are woody but some of which are herbaceous plant hosts $[3,4]$. The fungus may spread from adjacent infected trees through root-to-root contact or from wood debris of dead trees where P. noxius can remain viable in the soil for more than ten years, but it is still not clear whether air-borne basidiospores may function to establish new disease foci [1,4]. More recently, P. noxius has become a serious problem in urban areas, such as in Australia, Japan, Taiwan, Hongkong, 
and Macao, where it has killed trees, including a variety of perennial fruit trees, ornamental trees, and ancient tree species $[1,4,5]$. Therefore, tree health problems have attracted more and more attention in both the public and research realms. Although some efforts were made, and sometimes successfully, to prevent brown root rot disease spreading rapidly, such as removing all the infected trees and as many roots as possible, installing root barriers or ditching around the infected site to reduce the rate of spread, flooding the infested soil, and replanting resistant species in the infested areas [3,6], few reports have been involved in chemical controlling measure. An ammonia-based chemical reagent has been developed to be effective against $P$. noxius, but it has side effects on soil characteristics and root growth [7]. Recently, the chemical fumigant dazomet has been reported to be a possible means of preventing P. noxius incursion in agriculture [8]. In fact, there is no effective way to completely eliminate this fungus in soil by the existing chemical strategies. Moreover, synthetic fungicides might not be a good choice in urban areas, where extensive environmental contamination occurs. Nowadays, the biological control of $P$. noxius shows promise due to its environmental friendliness [5].

Naturally, phenazines are a large group of nitrogen-containing heterocyclic compounds, mainly synthesized by Streptomyces and Pseudomonas species [9], which play major roles in iron acquisition, respiration, redox balancing, signaling, and community development in their producers because of their redox activity [10]. Phenazine-1-carboxylic acid (PCA), an antibiotic that is the main active ingredient of Pseudomonas spp., which has a strong suppressive activity towards various plant fungal pathogens, nematodes (Caenorhabditis elegans) and Gram-negative bacterium (Xanthomonas oryzae) [9-11]. In China, PCA has been registered as the biofungicide "Shenqinbactin" because of its high fungicidal efficiency, low toxicity to humans and animals, environmental compatibility, and improvement of crop production [10,12]. In a recent study, the PCA had good antifungal activity against the major part of the 25 phytopathogenic fungi and oomycetes that they were mainly Ascomycetes or Deuteromycota, but one species Rhizoctonia solani assayed in that study belonging to Basidiomycota was shown to be highly tolerant to PCA [9]. However, there have been no further studies of how PCA affects those fungal pathogens. To our knowledge, there is no literature available on PCA inhibiting P. noxius attacking a variety of tree species. The objective of the present work is to evaluate the in vitro antifungal activity and to investigate how PCA affects $P$. noxius by biochemical and molecular methods.

\section{Results and Discussion}

\subsection{Effects of PCA on Growth and Morphology of P. noxius Mycelium}

The in vitro antifungal activity of PCA against mycelial growth of P. noxius was shown in Figure 1. The inhibition of fungal mycelial growth was obvious at 9 days compared to the non-PCA-treated group. PCA was able to completely inhibit the growth of P. noxius at $40 \mu \mathrm{g} / \mathrm{mL}$. This inhibition lasted for at least 30 days. Further details are shown in Figure 2. This fungus exhibited a slower growth rate when grown in potato dextrose broth (PDB) with the serial concentration $(1.25-20 \mu \mathrm{g} / \mathrm{mL})$ of PCA as compared to the non-PCA-treated group; moreover, PCA treatment significantly reduced the growth mycelial biomass. Both the inhibitory efficacy of mycelial growth and the loss of mycelial biomass were positively correlated with the PCA concentration.

\section{Control $\quad 1.25 \mu \mathrm{g} / \mathrm{mL} \quad 2.5 \mu \mathrm{g} / \mathrm{mL} \quad 5 \mu \mathrm{g} / \mathrm{mL} \quad 10 \mu \mathrm{g} / \mathrm{mL} \quad 20 \mu \mathrm{g} / \mathrm{mL} \quad 40 \mu \mathrm{g} / \mathrm{mL}$}

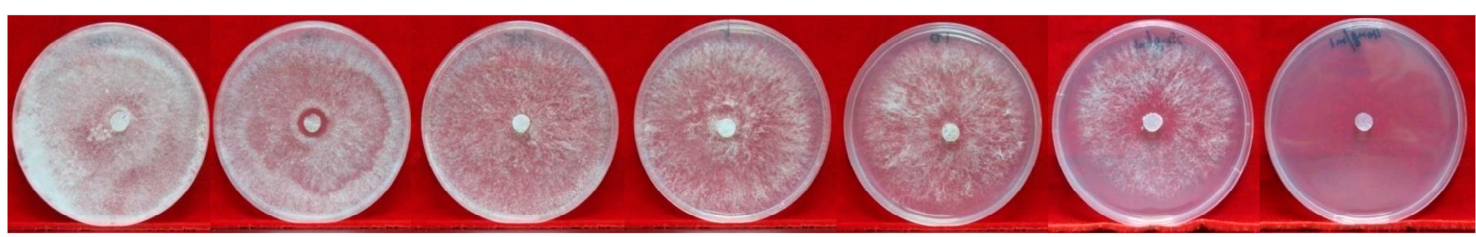

Figure 1. Growth inhibition of $P$. noxius on potato dextrose agar (PDA) plates in the presence or absence of the serial concentration $(1.25-40 \mu \mathrm{g} / \mathrm{mL})$ of phenazine-1-carboxylic acid. 


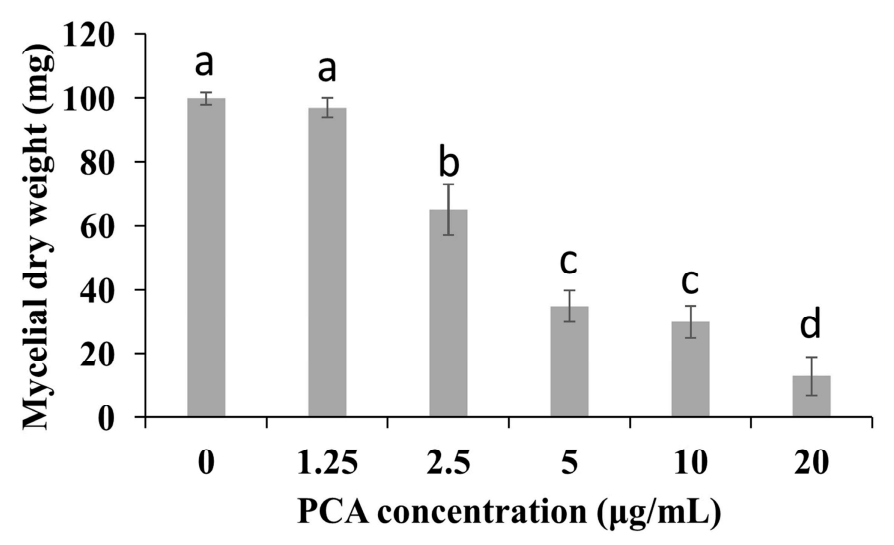

Figure 2. Effect of phenazine-1-carboxylic acid (PCA) on the dry weight of the mycelium of P. noxius in the presence or absence of the serial concentration $(1.25-20 \mu \mathrm{g} / \mathrm{mL})$ of PCA. Values were presented as mean \pm S.E. Data presented were the means of pooled data $(n=6)$. Values followed by a different lowercase letter are significantly different $(p<0.05)$.

Moreover, the hyphal morphological changes were examined via optical microscopy, which indicated that treatment with PCA had a significant effect on mycelia growth (Figure 3). After the PCA treatment, fungal hyphae revealed irregularly swollen mycelia and short hyphae with increased septation and less branching compared to the control intact mycelium with normal branching and septation. In this study, P. noxius hyphea treated with PCA were stained with methylene blue to determine viability. PCA-treated hyphae (approximately $30 \%$ in $10 \mu \mathrm{g} / \mathrm{mL}$ or $80 \%$ in $20 \mu \mathrm{g} / \mathrm{mL}$ ) retained the oxidized form of methylene blue because of the loss of the reducing capacity of the dead hyphae. However, the viable hyphae rapidly converted the methylene blue dye to its colorless form, leucomethylene blue, although the hyphae without PCA treatment showed a low level of staining with methylene blue $(<3 \%)$. Therefore, this finding indicated a fungicidal effect of PCA (Figure 4). Except for abnormal fungal growth caused by PCA (Figure 3B-D), it obviously caused cell lysis or cell death at concentrations above $20 \mu \mathrm{g} / \mathrm{mL}$.
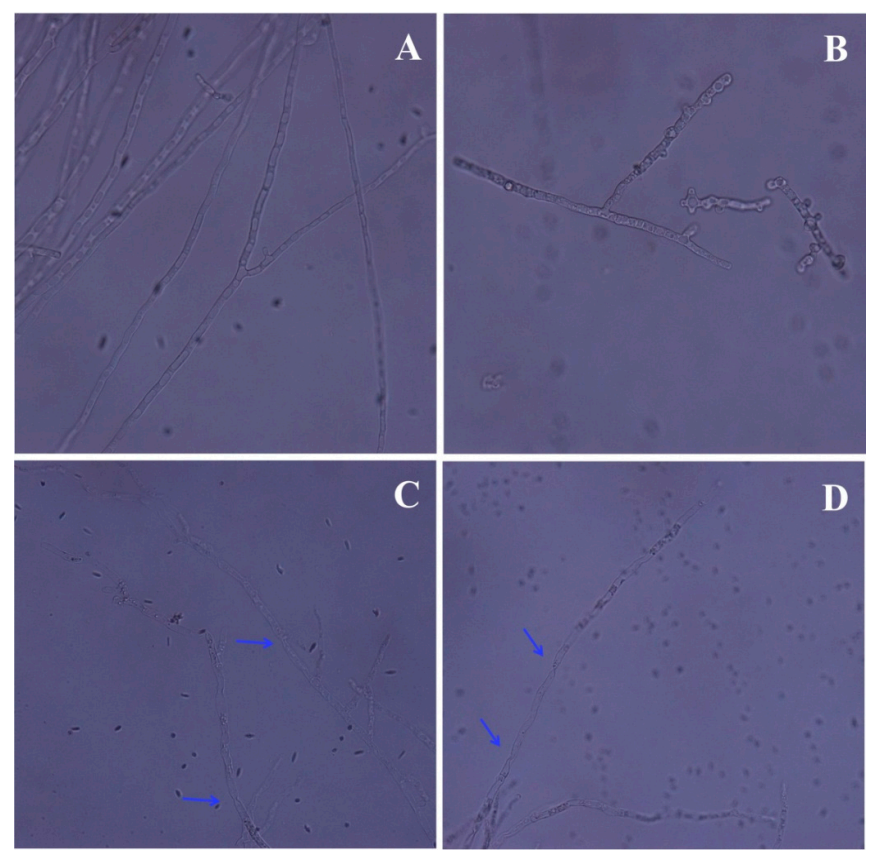

Figure 3. Optical microscopy of $P$. noxius mycelia with or without PCA $(40 \times)$. (A) Control; (B) $10 \mu \mathrm{g} / \mathrm{mL}$; (C) $20 \mu \mathrm{g} / \mathrm{mL}$; (D) $40 \mu \mathrm{g} / \mathrm{mL}$. 


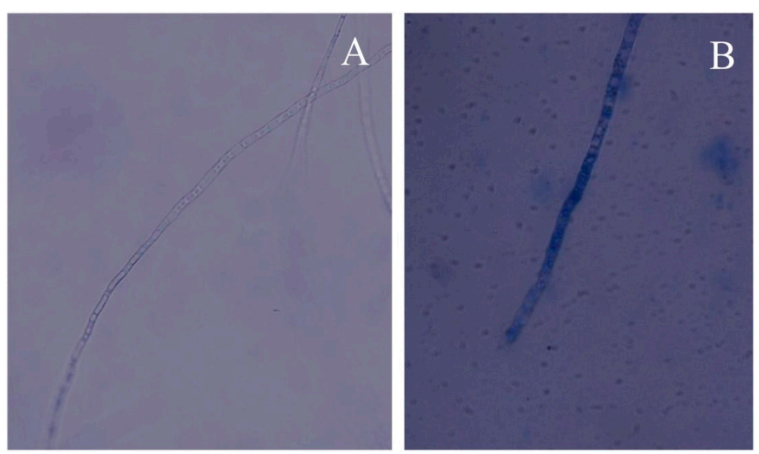

Figure 4. PCA-induced cell death confirmed by $0.02 \%$ methylene blue staining $(40 \times)$. (A) Control; (B) $20 \mu \mathrm{g} / \mathrm{mL}$ PCA.

The present study revealed that PCA had an obvious inhibitory effect on the hyphal growth of $P$. noxius. PCA inhibited both mycelial growth and the loss of mycelial biomass in vitro in a dose-dependent manner. It is known that PCA belongs to a group of antibiotic phenazines that is primarily derived from Pseudomonas spp. $[10,13]$ and has been reported to possess antimicrobial activity against a variety of phytopathogens such as Gaeumannomyces graminis [14], Seiridium cardinale [15], Phytophthora meadii [16], a Gram-negative bacterium X. oryzae [10], and a model nematode C. elegans [11]. Our results are in agreement with these previous studies demonstrating that PCA is characterized by high antimicrobial activity, though they showed a variable sensitivity to PCA, which may be because the different fungi have evolved different strategies to avoid several phenazine compounds $[9,10]$. In this study, we noticed the hyphae shape in most cells was completely altered by PCA, and lysis of hyphae occurred when exposed to PCA at concentrations above $20 \mu \mathrm{g} / \mathrm{mL}$. The similar lytic phenomenon of PCA was found when the zoospore suspensions of $P$. meadii were treated with PCA [16]. Some carboxylic acid-functionalized small molecules, such as a polyunsaturated long fatty acid-docosahexaenoic acid-and medium-chain saturated fatty acids and related compounds, were indicated as having fundamental effects on cell membrane by destabilizing lipid bilayers $[17,18]$, but membrane-lytic effects of PCA on P. noxius remain unclear.

\subsection{Mechanism of Action of PCA in P. noxius}

It is known that intracellular reactive oxygen species (ROS) are generated in cellular response to exogenous sources such as xenobiotics compounds and pathogen invasion as well as during mitochondrial oxidative metabolism [19]. To examine the intracellular ROS change by PCA, P. noxius protoplast cells were treated with PCA $(0-20 \mu \mathrm{g} / \mathrm{mL})$ for $1 \mathrm{~h}$, and ROS levels were measured by using the cell-permeable substrate $2^{\prime}, 7^{\prime}$-dichlorodihydrofluorescein diacetate (DCFH-DA). As shown in Figure 5A, the intracellular ROS accumulation in P. noxius was obviously affected by PCA. We found that the ROS product differed in the presence of PCA $(0-20 \mu \mathrm{g} / \mathrm{mL})$ and resulted in a significant increase in the intracellular fluorescence when compared to the control, indicating a higher ROS production in the group treated with PCA. The relative intensity of fluorescence as measured by fluorescence microplate reader increased from 556 arbitrary units (AUs) for cells in the absence of PCA to 1726 AUs in the presence of $20 \mu \mathrm{g} / \mathrm{mL}$ of PCA. Our results indicated that PCA generates ROS in P. noxius.

Mitochondria are considered the main source of ROS in the cell. Rhodamine 123 was used as a probe of mitochondrial membrane potential (MMP or $\triangle \Psi \mathrm{m}$ ) because of its reliable and sensitive evaluation [20]. As shown in Figure 5A, the presence of PCA $(5-10 \mu \mathrm{g} / \mathrm{mL})$ triggered hyperpolarization of MMP with a $150 \%$ increase in the relative fluorescence intensity in the P. noxius protoplast as compared to the non-PCA-treated group. However, the MMP at $20 \mu \mathrm{g} / \mathrm{mL}$ PCA was reduced, which could be the result of high sensitivity of protoplast cells when analyzed. Higher MMP was also reported in Benjaminiella poitrasii yeast cells treated with phenazine-1-carboxamide, which may lead to 
more ROS production [21]. In addition, superoxide dismutase (SOD) activities in P. noxius were found to be repressed by PCA at $2 \mathrm{~h}$ (Figure 6A), and CAT activity was increased by PCA at $2 \mathrm{~h}$, except for the higher concentration of PCA $(20 \mu \mathrm{g} / \mathrm{mL})$ (Figure $6 \mathrm{~B})$. The lower SOD and limited CAT activities in the presence of a higher amount of PCA $(20 \mu \mathrm{g} / \mathrm{mL})$ are likely to reduce ROS scavenging ability, which is consistent with a recent report on X. oryzae [10]. The results indicated that the higher levels of ROS in P. noxius triggered by PCA play important roles in antifungal action. Consistent with many previous reports, similar redox activities have been shown to be important for the antimicrobial activity of other phenazines, such as clofazimine [22], pyocyanin [23,24], 5-methylphenazine-1-carboxylic acid [25], and phenazine-1-carboxamide [21].
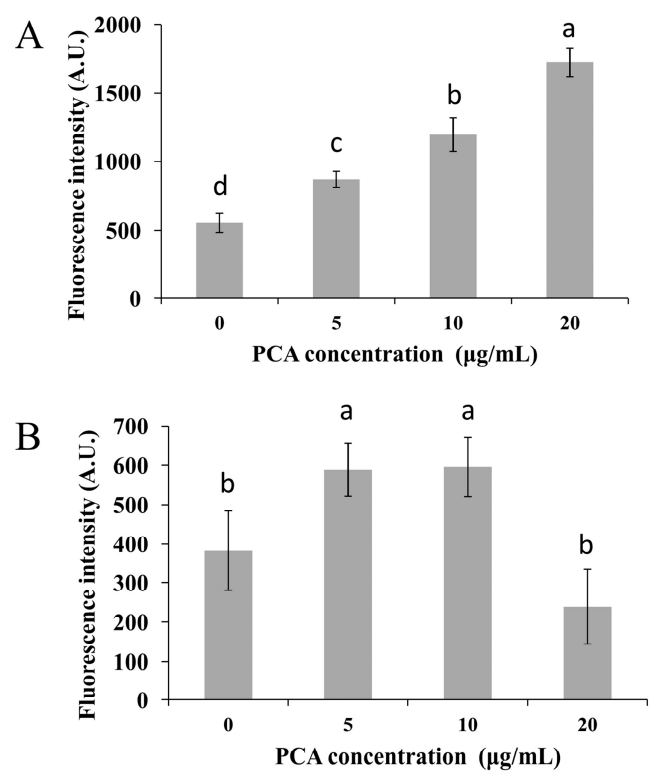

Figure 5. Effects of PCA on intracellular ROS accumulation (A) and mitochondrial membrane potential (B) in P. noxius. Values were presented as mean \pm S.E. Data presented were the means of pooled data $(n=6)$. Values followed by a different lowercase letter are significantly different $(p<0.05)$.

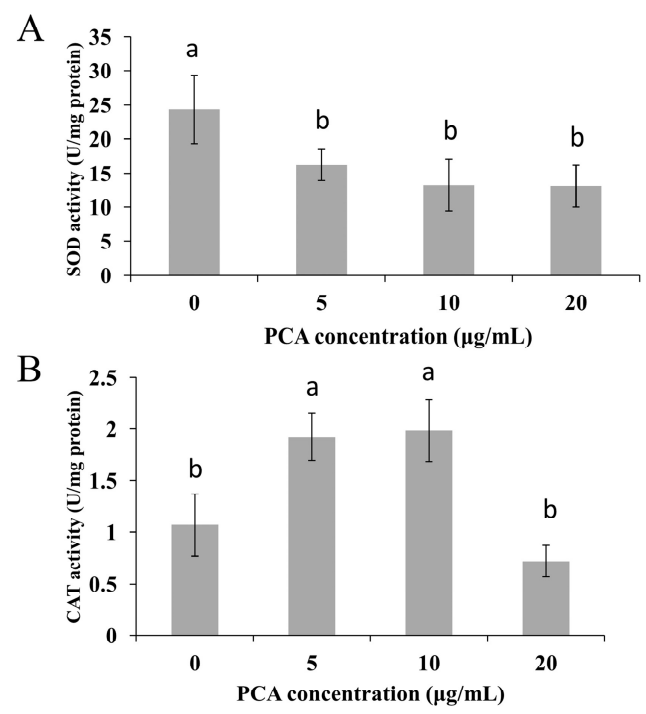

Figure 6. Effects of PCA on SOD (A) and CAT (B) in P. noxius. Values were presented as mean \pm S.E. Data presented were the means of pooled data $(n=6)$. Values followed by a different lowercase letter are significantly different $(p<0.05)$. 


\subsection{Effects of PCA on Gene Expression of P. noxius}

To determine if PCA was responsible for the change in gene expression, we selectively analyzed seven genes for qRT-PCR that are involved in cell detoxification, the oxidation-reduction process, and electron transport of the respiratory chain. The results are given in Figure 7; all seven genes were upregulated at all two time points in response to low-level PCA. Interestingly, the expression of genes at $24 \mathrm{~h}$ was more upregulated than those at $4 \mathrm{~h}$. It is well known that the ATP-binding cassette (ABC) and the major facilitator superfamily (MFS) transporters can play a major role not only in fungicide sensitivity and resistance but also in the efflux of toxic components and metabolites from the cell [26]. Furthermore, they are involved in a large variety of molecular events such as protein secretion, nutrient uptake, and pathogenesis [27]. In this study, all three selected cellular transport-related genes were upregulated in response to PCA, suggesting that they could be involved in PCA detoxification in order to improve the cell viability.

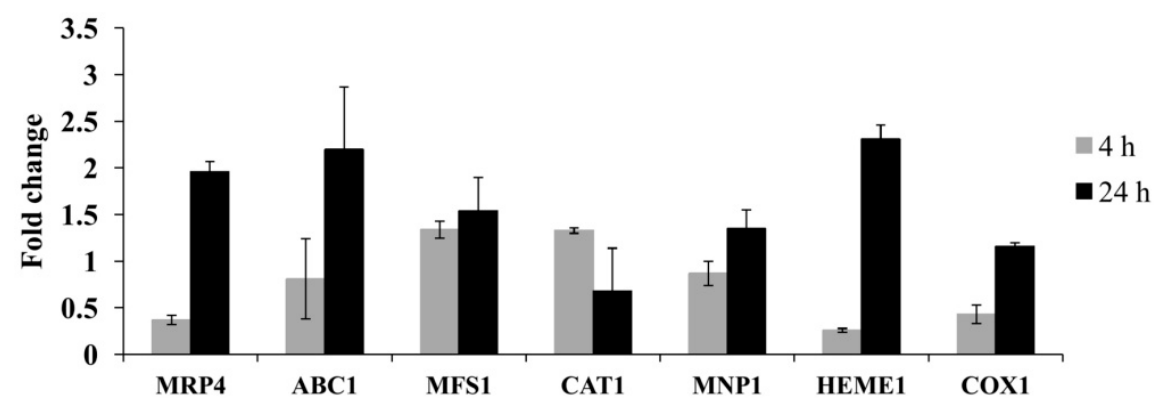

Figure 7. Gene expression profile of seven selected P. noxius genes treated with $5 \mu \mathrm{g} / \mathrm{mL}$ PCA for $4 \mathrm{~h}$ and $24 \mathrm{~h}$. Relative expression levels in relation to elongation factor 1-alpha expression are calculated from $\mathrm{Ct}$ values according to the $2^{-\Delta \Delta \mathrm{Ct}}$ method.

Peroxidases are heme-containing enzymes that use hydrogen peroxide as the electron acceptor to catalyze a number of oxidative reactions. The expression of manganese peroxidase (MNP) is often induced by a heat shock in nitrogen-limited cultures and regulated by $\mathrm{H}_{2} \mathrm{O}_{2}$ and various chemicals [28]. The MNP1 gene was upregulated by PCA in this study. In addition, the previous study revealed that most fungal species have multiple copies of catalase genes, which might function independently by individual catalases or cooperatively by catalase gene family members $[29,30]$. Catalases are enzymes responsible for the degradation of $\mathrm{H}_{2} \mathrm{O}_{2}$ and protection of the cell against oxidative stress and ROS accumulation. However, the upregulation of catalases in this study may be the result of a compensatory mechanism for increasing catalase activity, which is inhibited by PCA in an attempt to protect the cell in response to PCA-induced apoptotic cell death effects. Cytochrome c oxidase subunit 1 (COX1) is a gene encoded for the mitochondria-encoded respiratory chain subunit. COX1 was upregulated in response to PCA in this study, which indicated that PCA induces the gene expression in P. noxius associated with mitochondrial respiration. Therefore, consistent with previous published data, PCA, like other phenazines, can impact mitochondrial activity [10,31].

\section{Materials and Methods}

\subsection{Fungal Strain, Culture Conditions, and Chemicals}

Phellinus noxius was obtained from infected tree roots (Sterculia lanceolata) in Guia Hill Municipal Park of Macao. Fungal isolate was stored in sterile tubes containing potato dextrose agar (PDA) and routinely grown on PDA plates. PCA ( $>98 \%)$ was a generous gift from Prof. He Yawen (Shanghai Jiao Tong University) [32]. For addition to cultures, PCA was dissolved in chloroform/methanol $(4: 1, v / v)$ as indicated. All other chemicals and regents are of analytical grade purchased in China. 


\subsection{Effects of Inhibition of PCA in P. noxius on PDA Plate and PDB Medium in Vitro}

The sensitivity of $P$. noxius to PCA was assessed in PDA plates. Mycelial discs (5 mm) were removed from one-week-old PDA plates and placed in the center of a 90-mm-diameter petri plate containing PDA plates supplemented with six different concentrations of PCA $(1.25,2.5,5,10,20$, and $40 \mu \mathrm{g} / \mathrm{mL}$ ), these plates without PCA as control. Each treatment was performed in triplicate. The petri plates were incubated at $30^{\circ} \mathrm{C}$ for 9 days, and radial growth was measured at the end of the trial. Growth inhibition of P. noxius by PCA was quantified as described previously [9].

For PDB medium, $150 \mathrm{~mL}$ conical flasks containing $40 \mathrm{~mL}$ of potato dextrose broth (PDB) supplemented with five different concentrations of PCA $(1.25,2.5,5,10$, and $20 \mu \mathrm{g} / \mathrm{mL})$ were inoculated with mycelial discs $(5 \mathrm{~mm})$, excised from one-week-old PDA plates with chloroform/methanol $(0.1 \%$, $v / v)$ as control. Each treatment was performed in triplicate. Flasks were incubated on a rotary shaker (220 rpm) at $30{ }^{\circ} \mathrm{C}$ for 6 days. After $72 \mathrm{~h}$, mycelia were examined under optical microscopy (Nikon DS-Ril-U2, Tokyo, Japan). At the end of the incubation period, mycelia were collected from each flask, dried at $80^{\circ} \mathrm{C}$, and then weighed.

\subsection{Effect of PCA on Intracellular Reactive Oxygen Species (ROS) Accumulation in P. noxius}

Intracellular ROS accumulation was measured with a ROS assay kit (Beyotime, Nantong, China) according to the instruction manual. In brief, Protoplasts from fungal vegetative hyphae were produced as described previously [33] and stabilized in STC medium (1.0 M sorbitol, $10 \mathrm{mM}$

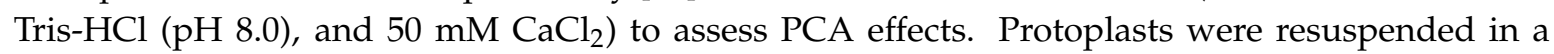
$2^{\prime}, 7^{\prime}$-dichlorodihydrofluorescein diacetate (DCFH-DA) solution (1:1000 diluted with STC medium). The fungal suspensions were then incubated at $30^{\circ} \mathrm{C}$ for $20 \mathrm{~min}$ in the centrifuge tubes, which were inverted every $5 \mathrm{~min}$. Extracellular DCFH-DA was removed by centrifugation at $6000 \mathrm{rpm}$ for $8 \mathrm{~min}$ at room temperature, followed by three washes with STC medium, and the cells were then resuspended in STC medium. The 96-well plates were treated with PCA $(5-20 \mu \mathrm{g} / \mathrm{mL})$ and chloroform $/ \mathrm{methanol}$ $(0.2 \%, v / v)$ as control, and $1 \times 10^{4}$ cells were then added to each well. Each assay contained triplicates for each concentration. The oxidation of DCFH by ROS was determined by measuring the mean fluorescent intensity of DCFH by a Synergy H1 Microplate reader (Biotek, Winooski, VT, USA) at $488 \mathrm{~nm}$ excitation $/ 525 \mathrm{~nm}$ emission.

\subsection{Effect of PCA on Mitochondrial Membrane Potential (MMP)}

The MMP assay was performed essentially as described in [21], and Protoplast cells $\left(1 \times 10^{6}\right.$ cells $\left./ \mathrm{mL}\right)$ were suspended in STC medium containing different concentrations of PCA $(5-20 \mu \mathrm{g} / \mathrm{mL})$ and kept at $30{ }^{\circ} \mathrm{C}$ for $120 \mathrm{~min}$. After $120 \mathrm{~min}, 1 \mu \mathrm{M}$ Rhodamine 123 was added and further incubated for $30 \mathrm{~min}$. Each assay contained triplicates for each concentration. The fluorescence intensities were measured by a Synergy H1 Microplate reader (Biotek) at $480 \mathrm{~nm}$ excitation/525 $\mathrm{nm}$ emission.

\subsection{Effects of PCA on Activities of Superoxide Dismutase (SOD) and Catalase (CAT) in P. noxius}

P. noxius was grown in yeast peptone dextrose (YPD) medium for two days, which was then diluted 20 times in fresh YPD medium supplemented with different concentrations of PCA $(5-20 \mu \mathrm{g} / \mathrm{mL})$ and chloroform/methanol $(0.1 \%, v / v)$ as control. Fungal mycelia were collected after incubation at $30^{\circ} \mathrm{C}$ for $2 \mathrm{~h}$. Each assay contained triplicates for each concentration. Enzyme activities of SOD and CAT were assayed and calculated with a SOD assay kit (Total SOD) and CAT assay kit as previously described [10].

\subsection{Quantitative Real-Time PCR}

Mycelial discs ( $5 \mathrm{~mm}$ ) excised from one-week-old PDA plates were used to inoculate $50 \mathrm{~mL}$ of PDB in 150-mL conical flasks. The flasks were incubated at $30^{\circ} \mathrm{C} / 250 \mathrm{rpm}$ for two days. Mycelia 
were aseptically transferred to $200 \mathrm{~mL}$ fresh PDB medium in the presence or absence of $5 \mu \mathrm{g} / \mathrm{mL}$ PCA. Mycelia were harvested by filtration through two-layer cheesecloth after $4 \mathrm{~h}$ and $24 \mathrm{~h}$, washed thoroughly with sterile water, quickly frozen in liquid nitrogen, and disrupted by grinding, and total RNA was extracted with TRIzol reagent (Invitrogen) and reverse transcribed into cDNA with ReverTra Ace qPCR RT Master Mix with gDNA Remover (Toyobo life science, Shanghai, China) according to the instruction manual. Seven genes were analyzed, including three cellular transport-related genes [multidrug resistance protein 4 (MRP4), a ATP-binding cassette protein (ABC1) and a MFS transporter (MFS1)], three peroxidase genes (catalase (CAT1), manganase peroxidase 1 (MNP1) and a heme peroxidase (HEME1)), a component of the mitochondrial electron transport chain (cytochrome c oxidase subunit 1, COX1), and elongation factor 1-alpha (EF1 $\alpha)$ was used as reference gene. The qRT-PCR reactions were performed using SYBR Premix Ex Taq (Perfect Real Time) (Takara, Dalian, China) and the Thermal Cycler Dice Real Time System (Takara) according to the manufacturer's protocol. Primers used in this study are listed in Table 1. The relative changes in the gene expression were quantified using the $2^{-\Delta \Delta C t}$ method [34].

Table 1. Oligonucleotide primers used for qRT-PCR.

\begin{tabular}{|c|c|c|c|}
\hline Gene Name & Putative Function & Sequence $\left(5^{\prime}-3^{\prime}\right)^{1}$ & Amplicon (bp.) \\
\hline \multirow{2}{*}{ MRP4 } & \multirow{2}{*}{ multidrug resistance protein 4} & GGGTTTGACCTCTATCCGAA (F) & \multirow[t]{2}{*}{105} \\
\hline & & CCAGCAACATCGACCAATAC (R) & \\
\hline \multirow[t]{2}{*}{$\mathrm{ABC} 1$} & \multirow[t]{2}{*}{ ATP-binding cassette protein } & AGTGCTCGTGAAATGAAACG (F) & \multirow[t]{2}{*}{96} \\
\hline & & ACTCCGAATGGTGGCTAATC (R) & \\
\hline \multirow[t]{2}{*}{ MFS1 } & \multirow[t]{2}{*}{ MFS transporter } & CTCCGGTTCAACATCACATC (F) & \multirow[t]{2}{*}{105} \\
\hline & & AAGGGTCATCTGGTCCATTC (R) & \\
\hline \multirow[t]{2}{*}{ CAT1 } & \multirow[t]{2}{*}{ catalase } & CCTTACGATTCTCCACCGTT (F) & \multirow[t]{2}{*}{107} \\
\hline & & CCAATCAAGATTTCCGTCCT (R) & \\
\hline \multirow[t]{2}{*}{ MNP1 } & \multirow[t]{2}{*}{ manganese peroxidase 1} & TCTACGATCTTGCTGATGCC (F) & \multirow[t]{2}{*}{91} \\
\hline & & TCGTGGAAAGTGAGACGAAG (R) & \\
\hline \multirow[t]{2}{*}{ HEME1 } & \multirow[t]{2}{*}{ heme peroxidase } & ATCGGATCAAATGGGTTCAT (F) & \multirow[t]{2}{*}{98} \\
\hline & & GGCCATTTCATGGCTCTTAT (R) & \\
\hline \multirow[t]{2}{*}{ COX1 } & \multirow[t]{2}{*}{ cytochrome c oxidase subunit 1} & TTTAACCTTGGTTTCACTGATGA (F) & \multirow[t]{2}{*}{85} \\
\hline & & GGTCACTGATAGGTGGCTGA (R) & \\
\hline \multirow[t]{2}{*}{$\mathrm{EF} 1 \alpha$} & \multirow{2}{*}{ elongation factor 1-alpha } & ACGGCGGATATCCTTAACTG (F) & \multirow[t]{2}{*}{107} \\
\hline & & CTGAAGTGAAGTCCGTCGAA (R) & \\
\hline
\end{tabular}

${ }^{1}$ F: Forward primer; R: Reverse primer.

\subsection{Statistical Analysis}

A completely randomized design was used for all treatments. Data were presented as mean \pm standard error (SE). The mean separations were carried out using Duncan's multiple range tests, and significance was determined at 5\% level (SPSS Version 19.0, IBM, New York, NY, USA) [35].

\section{Conclusions}

In the current study, it demonstrated that PCA could significantly inhibit the mycelial growth of $P$. noxius in vitro in a dose-dependent manner. PCA-treated fungus showed the arrested growth or eventual cell death, as evidenced by the release of a low level of SOD, the production of reactive oxygen species, high mitochondrial membrane potential, and morphological characteristics. At the molecular level, to our knowledge, this is the first study of gene expression for P. noxius in response to an antifungal agent PCA. Our results indicated that PCA has a broad spectrum of cellular effects. Due to its innate inhibition potential, PCA may be used as a potent antifungal agent to control P. noxius that attacks a variety of tree species.

Acknowledgments: This work was partially supported by Governo da Região Administrativa Especial de Macau, Instituto Para os Assuntos Civicos e Municipais (IACM). 
Author Contributions: The listed authors contributed to this work as follows: M.H. and G.Z. conceived and designed the experiments; H.H., L.S., and K.B. carried out the experiments; H.H. and L.S. analyzed the data; H.H., G.Z., and M.H. wrote the manuscript. All authors read and approved the final manuscript.

Conflicts of Interest: The authors declare no conflict of interest.

\section{References}

1. Akiba, M.; Ota, Y.; Tsai, I.J.; Hattori, T.; Sahashi, N.; Kikuchi, T. Genetic differentiation and spatial structure of Phellinus noxius, the causal agent of brown root rot of woody plants in Japan. PLoS ONE 2015, 10, e0141792.

2. Sahashi, N.; Akiba, M.; Takemoto, S.; Yokoi, T.; Ota, Y.; Kanzaki, N. Phellinus noxius causes brown root rot on four important conifer species in Japan. Eur. J. Plant Pathol. 2014, 140, 869-873. [CrossRef]

3. Ann, P.J.; Chang, T.T.; Ko, W.H. Phellinus noxius brown root rot of fruit and ornamental trees in Taiwan. Plant Dis. 2002, 86, 820-826. [CrossRef]

4. $\quad$ Chung, C.L.; Huang, S.Y.; Huang, Y.C.; Tzean, S.S.; Ann, P.J.; Tsai, J.N.; Yang, C.C.; Lee, H.H.; Huang, T.W.; Huang, H.Y.; et al. The Genetic structure of Phellinus noxius and dissemination pattern of brown root rot disease in Taiwan. PLoS ONE 2015, 10, e0139445. [CrossRef] [PubMed]

5. Schwarze, F.W.; Jauss, F.; Spencer, C.; Hallam, C.; Schubert, M. Evaluation of an antagonistic Trichoderma strain for reducing the rate of wood decomposition by the white rot fungus Phellinus noxius. Biol. Control. 2012, 61, 160-168. [CrossRef]

6. Chang, T.T. Survival of Phellinus noxius in soil and in the roots of dead host plants. Phytopathology 1996, 86, 272-276. [CrossRef]

7. Chang, T.T.; Chang, R.J. Generation of volatile ammonia from urea fungicidal to Phellinus noxius in infested wood in soil under controlled conditions. Plant Pathol. 1999, 48, 337-344. [CrossRef]

8. Fu, C.H.; Hu, B.Y.; Chang, T.T.; Hsueh, K.L.; Hsu, W.T. Evaluation of dazomet as fumigant for the control of brown root rot disease. Pest Manag. Sci. 2012, 68, 959-962. [CrossRef] [PubMed]

9. Puopolo, G.; Masi, M.; Raio, A.; Andolfi, A.; Zoina, A.; Cimmino, A.; Evidente, A. Insights on the susceptibility of plant pathogenic fungi to phenazine-1-carboxylic acid and its chemical derivatives. Nat. Prod. Res. 2013, 27, 956-966. [CrossRef] [PubMed]

10. Xu, S.; Pan, X.; Luo, J.; Wu, J.; Zhou, Z.; Liang, X.; He, Y.; Zhou, M. Effects of phenazine-1-carboxylic acid on the biology of the plant-pathogenic bacterium Xanthomonas oryzae pv. oryzae. Pest Biochem. Physiol. 2015, 117, 39-46. [CrossRef] [PubMed]

11. Cezairliyan, B.; Vinayavekhin, N.; Grenfell-Lee, D.; Yuen, G.J.; Saghatelian, A.; Ausubel, F.M. Identification of Pseudomonas aeruginosa phenazines that kill Caenorhabditis elegans. PLoS Pathog. 2013, 9, e1003101. [CrossRef] [PubMed]

12. Yuan, L.L.; Li, Y.Q.; Wang, Y.; Zhang, X.H.; Xu, Y.Q. Optimization of critical medium components using response surface methodology for phenazine-1 -carboxylic acid production by pseudomonas sp. M-18Q. J. Biosci. Bioeng. 2008, 105, 232-237. [CrossRef] [PubMed]

13. Huang, Z.; Bonsall, R.F.; Mavrodi, D.V.; Weller, D.M.; Thomashow, L.S. Transformation of Pseudomonas fluorescens with genes for biosynthesis of phenazine-1-carboxylic acid improves biocontrol of rhizoctonia root rot and in situ antibiotic production. FEMS Microbiol. Ecol. 2004, 49, 243-251. [CrossRef] [PubMed]

14. Thomashow, L.S.; Weller, D.M.; Bonsall, R.F.; Pierson, L.S. Production of the antibiotic phenazine-1-carboxylic acid by fluorescent pseudomonas species in the rhizosphere of wheat. Appl. Environ. Microbiol. 1990, 56, 908-912. [PubMed]

15. Raio, A.; Puopolo, G.; Cimmino, A.; Danti, R.; Della Rocca, G.; Evidente, A. Biocontrol of cypress canker by the phenazine producer Pseudomonas chlororaphis subsp. Aureofasciens strain M71. Biol. Control. 2011, 58, 133-138. [CrossRef]

16. Abraham, A.; Philip, S.; Jacob, M.K.; Narayanan, S.P.; Jacob, C.K.; Kochupurackal, J. Phenazine-1-carboxylic acid mediated anti-oomycete activity of the endophytic Alcaligenes sp. EIL-2 against Phytophthora meadii. Microbiol. Res. 2015, 170, 229-234. [CrossRef] [PubMed]

17. Thid, D.; Benkoski, J.J.; Svedhem, S.; Kasemo, B.; Gold, J. DHA-induced changes of supported lipid membrane morphology. Langmuir 2007, 23, 5878-5881. [CrossRef] [PubMed]

18. Yoon, B.K.; Jackman, J.A.; Kim, M.C.; Cho, N.J. Spectrum of membrane morphological responses to antibacterial fatty acids and related surfactants. Langmuir 2015, 31, 10223-10232. [CrossRef] [PubMed] 
19. Ray, P.D.; Huang, B.W.; Tsuji, Y. Reactive oxygen species (ROS) homeostasis and redox regulation in cellular signaling. Cell. Signal. 2012, 24, 981-990. [CrossRef] [PubMed]

20. Baracca, A.; Sgarbi, G.; Solaini, G.; Lenaz, G. Rhodamine 123 as a probe of mitochondrial membrane potential: evaluation of proton flux through $\mathrm{F}_{0}$ during ATP synthesis. BBA-Bioenergetics 2003, 1606, 137-146. [CrossRef]

21. Tupe, S.G.; Kulkarni, R.R.; Shirazi, F.; Sant, D.G.; Joshi, S.P.; Deshpande, M.V. Possible mechanism of antifungal phenazine-1-carboxamide from Pseudomonas sp. against dimorphic fungi Benjaminiella poitrasii and human pathogen Candida albicans. J. Appl. Microbiol. 2015, 118, 39-48. [CrossRef] [PubMed]

22. Yano, T.; Kassovska-Bratinova, S.; The, J.S.; Winkler, J.; Sullivan, K.; Isaacs, A.; Schechter, N.M.; Rubin, H. Reduction of clofazimine by mycobacterial type 2 NADH:quinone oxidoreductase: A pathway for the generation of bactericidal levels of reactive oxygen species. J. Biol. Chem. 2011, 286, 10276-10287. [CrossRef] [PubMed]

23. Hassan, H.M.; Fridowich, I. Mechanism of antibiotic action of pyocyanin. J. Bacteriol. 1980, 141, $156-163$. [PubMed]

24. Muller, M. Pyocyanin induces oxidative stress in human endothelial cells and modulates the glutathione redox cycle. Free Radic. Biol. Med. 2002, 33, 1527-1533. [CrossRef]

25. Morales, D.K.; Jacobs, N.J.; Rajamani, S.; Krishnamurthy, M.; Cubillos-Ruiz, J.R.; Hogan, D.A. Antifungal mechanisms by which a novel Pseudomonas aeruginosa phenazine toxin kills Candida albicans in biofilms. Mol. Microbiol. 2010, 78, 1379-1392. [CrossRef] [PubMed]

26. Del Sorbo, G.; Schoonbeek, H.; De Waard, M.A. Fungal transporters involved in efflux of natural toxic compounds and fungicides. Fungal Genet. Biol. 2000, 30, 1-15. [CrossRef] [PubMed]

27. Cervelatti, E.P.; Fachin, A.L.; Ferreira-Nozawa, M.S.; Martinez-Rossi, N.M. Molecular cloning and characterization of a novel ABC transporter gene in the human pathogen Trichophyton rubrum. Med. Mycol. 2006, 44, 141-147. [CrossRef]

28. Li, D.; Alic, M.; Brown, J.A.; Gold, M.H. Regulation of manganese peroxidase gene transcription by hydrogen peroxide, chemical stress, and molecular oxygen. Appl. Environ. Microbiol. 1995, 61, 341-345. [PubMed]

29. Kawasaki, L.; Aguirre, J. Multiple catalase genes are differentially regulated in Aspergillus nidulans. J. Bacteriol. 2001, 183, 1434-1440. [CrossRef] [PubMed]

30. Johnson, C.H.; Klotz, M.G.; York, J.L.; Kruft, V.; McEwen, J.E. Redundancy, phylogeny and differential expression of Histoplasma capsulatum catalases. Microbiology 2002, 148, 1129-1142. [CrossRef] [PubMed]

31. Morales, D.K.; Grahl, N.; Okegbe, C.; Dietrich, L.E.; Jacobs, N.J.; Hogan, D.A. Control of Candida albicans metabolism and biofilm formation by Pseudomonas aeruginosa phenazines. mBio 2013, 4, e00526-e00512. [CrossRef] [PubMed]

32. Zhou, L.; Jiang, H.X.; Sun, S.; Yang, D.D.; Jin, K.M.; Zhang, W.; He, Y.W. Biotechnological potential of a rhizosphere Pseudomonas aeruginosa strain producing phenazine-1-carboxylic acid and phenazine-1-carboxamide. World J. Microbiol. Biotechnol. 2016, 32. [CrossRef] [PubMed]

33. Churchill, A.; Ciuffetti, L.; Hansen, D.; van Etten, H.; van Alfen, N. Transformation of the fungal pathogen Cryphonectria parasitica with a variety of heterologous plasmids. Curr. Genet. 1990, 17, 25-31. [CrossRef]

34. Livak, K.J.; Schmittgen, T.D. Analysis of relative gene expression data using real-time quantitative PCR and the $2^{-\Delta \Delta C t}$ method. Methods 2001, 25, 402-408. [CrossRef] [PubMed]

35. Chung, R.S.; Chen, C.C.; Ng, L.T. Nitrogen fertilization affects the growth performance, betaine and polysaccharide concentrations of Lycium barbarum. Ind. Crops Prod. 2010, 32, 650-655. [CrossRef]

Sample Availability: Not Available.

(C) 2016 by the authors; licensee MDPI, Basel, Switzerland. This article is an open access article distributed under the terms and conditions of the Creative Commons Attribution (CC-BY) license (http://creativecommons.org/licenses/by/4.0/). 